\title{
KAPABILITAS APARAT PEMERINTAH DAERAH DALAM MEMBERIKAN PELAYANAN ADMINISTRASI KEPENDUDUKAN DI KELURAHAN GEMPOLSARI KOTA BANDUNG
}

\author{
Anika Anjani \\ Prodi Ilmu Pemerintahan, Fakultas Ilmu Sosial dan Ilmu Politik, \\ Universitas Jenderal Achmad Yani Cimahi - Bandung
}

\begin{abstract}
Abstrak
Penelitian ini dilatarbelakangi oleh adanya masalah-masalah dalam kapabilitas apparat Pemerintah Daerah dalam memberikan pelayanan administrasi kependudukan, sehingga perlu diteliti lebih lanjut. Tujuan penelitian adalah untuk mengetahui sejauhmana peningkatan kinerja aparat Keluarahan Gempolsari dalam memberikan pelayanan administrasi kependudukan di Kelurahan Gempolsari Kota Bandung. Metode penelitian yang digunakan adalah penelitian deskriptif dengan pendekatan kualitatif. Data diolah dengan cara reduksi data, kategorisasi data, sintesisasi dan menyusun hipotesis kerja sebagai langkah terakhir pada proses penyusunan data. Hasil penelitian menunjukan bahwa Kapabilitas Aparat Pemerintah Daerah dalam memberikan pelayanan administrasi Kependudukan di Kelurahan Gempolsari Kota Bandung belum berhasil meningkatkan kinerjanya sesuai yang diharapkan dikarenakan, belum optimalnya pelayanan yang diberikan oleh aparat Pemerintahan terhadap pemohon pengajuan pelayanan administrasi kependudukan.
\end{abstract}

Kata Kunci: Kapabilitas, Aparat Pemerintah Daerah, Pelayanan Administrasi Kependudukan

\begin{abstract}
This research is motivated by a problem in the capability of local government officials in providing population administration services so that it needs to be further investigated. The research objective was to determine the extent of the improvement in the performance of the Gempolsari family officers in providing population administration services in Gempolsari Village, Bandung City. The research method used is descriptive research with a qualitative approach. The data is processed using data reduction, data categorization, synthesis, and formulation of working hypotheses as to the final step in the data compilation process. The results showed that the capability of Regional Government Officials in providing Population administration services in Gempolsari Village, Bandung City has not succeeded in increasing their performance as expected because the services provided by Government officials have not been optimal for applicants for demographic administration services.
\end{abstract}

Keywords: Capability, Local Government Officials, Population Administration Services 


\section{PENDAHULUAN}

Desentralisasi pada dasarnya merupakan pemberian sebagian dari wewenang pemerintahan pusat kepada daerah dalam melaksanakan dan menyelesaikan urusan yang menjadi tanggung jawab kepentingan daerah yang meliputi: urusan umum pemerintahan, urusan penyelesaian fasilitas pelayanan, sosial, budaya, agama dan kemasyarakatan. Keseluruhan urusan tersebut pada dasarnya sangat bergantung pada kemampuan aparatur daerah dalam menyelenggarakan urusan pemerintahan, untuk itu dibutuhkan suatu upaya peningkatan kemampuan organisasional yang baik dalam perumusan pengambilan kebijakan publik yang disesuaikan dengan kondisi finansial daerah.

Fakta-fakta yang terkandung dalam kebijakan desentralisasi sudah sangat baik, namun tetap membutuhkan prakondisi yang komprehensif agar berjalan dengan optimal. Beberapa prakondisi itu diantaranya adalah bahwa desentralisasi harus didukung oleh perencanaan yang matang dan ditopang oleh kemampuan atau kapasitas daerah untuk menjalankannya, baik pada tataran individu, organisasi, maupun sistem. Dengan demikian, kebijakan desentralisasi masih menghadapi tantangan yang berat, dan oleh karenanya butuh komitmen dari seluruh komponen di daerah untuk membuktikan diri bahwa otonomi daerah benar-benar membawa manfaat bagi seluruh lapisan masyarakat. Satu hal yang pasti adalah bahwa desentralisasi dan otonomi daerah tidak dapat ditarik mundur. Satusatunya pilihan adalah bekerja keras untuk mensukseskan otonomi daerah demi tercapainya peningkatan kualitas hidup bagi seluruh masyarakat di daerah.

Dalam hal ini kapabilitas suatu Pemerintahan baik pusat maupun daerah dapat dijadikan tolak ukur kesuksesan sebuah otonomi daerah, karena Pemerintah Pusat maupun Pemerintahan Daerah merupakan garis koordinasi yang saling berhubungan, salah satu kapabilitas yang harus dimiliki oleh pemerintah selaku pemegang kekuasaan tertinggi pada suatu negara maupun daerah merupakan mempertahankan kinerja aparatnya. 
Menurut Makadok (dalam Kusumasari 2014:44) Kapabilitas sebagai jenis khusus dari sumber daya yang tidak dapat diganti dan melekat pada organisasi yang tujuannya untuk meningkatkan produktivitas sumber daya lainnya. Barney dan Clark (dalam Kusumasari 2014:44) mendefinisikan kapabilitas sebagai atribut organisasi, seperti modal keuangan, fisik, dan individu/organisasi yang dapat dieksploitasi dalam penerapan strategi organisasi.

Merujuk pada permasalahan yang ada di Kota Bandung, berdasarkan Laporan Wartawan Tribun Jabar, Cipta Permana: Dinas Kependudukan dan Catatan Sipil (Disdukcapil) Kota Bandung terus berupaya untuk mengejar target ketertinggalan pelayanan bagi warga yang belum melakukan perekaman KTP elektronik (e-KTP). Bahkan untuk mengefektifkan hal tersebut, sejumlah petugas diturunkan ke berbagai wilayah di Kota Bandung. Kelurahan yang salah satu fungsinya memberikan pelayanan, pada kenyataannya dalam proses pemberian layanan administrasi kependudukan di Kelurahan Gempolsari Kota Bandung, masyarakat merasa pelayanan yang ada dan diberikan belum optimal, hal tersebut terjadi karena sumber daya manusia yang kurang dalam segi kuantitas sehingga pemberian pelayananannya pun memerlukan waktu yang cukup lama. Masyarakat Gempolsari dewasa ini sebagian besar sudah mulai memiliki kesadaran akan pentingnya pengurusan Dokumen Kependudukan, namun yang menjadi masalah dan sangat disayangkan ketika kita kembali lagi pada aparat pelaksananya sebagai item penyelenggara yang harus lebih ditingkatkan lagi.

Administrasi kependudukan ini mulai dari hal pengurusan administrasi yang menyangkut seluruh masalah kependudukan meliputi pendaftaran penduduk, pencatatan sipil, pengelolaan data-informasi kependudukan belum dirasa optimal secara keseluruhan dalam memberikan pelayanan yang sesuai dengan yang di amanatkan UndangUndang sehingga patut menjadi perhatian untuk segera melakukan evaluasi terhadap prosedur pelayanan pengurusan administratif identitas warga dengan penyelenggaraan administrasi kependudukan yang bersih, 
jujur dan transparan sesuai ketentuan UU Administrasi Kependudukan untuk mewujudkannya. Sampai saat ini peraturan perundang- undangan yang mendukungnya masih terpisah-pisah, berjalan sendiri-sendiri tanpa ada kaitan satu dengan lainnya. Perwujudan suatu sistem memang sangat didambakan oleh masyarakat. Bahkan, sebagai ciri dari penyelenggaraan negara yang modern khususnya bidang pelayanan masyarakat.

Tabel 1.1

Data Pengajuan Pelayanan Administrasi Kependudukan di Kelurahan Gempolsari Kota Bandung

\begin{tabular}{|c|c|c|c|c|}
\hline No & $\begin{array}{c}\text { Pengajuan } \\
\text { Pelayanan } \\
\text { Administrasi } \\
\text { Kependudukan }\end{array}$ & $\begin{array}{c}\text { Data yang } \\
\text { sudah } \\
\text { terealisasi }\end{array}$ & $\begin{array}{c}\text { Data yang } \\
\text { belum } \\
\text { teralisasi }\end{array}$ & Total \\
\hline 1 & Juli 2017 & 171 & 62 & 233 \\
\hline 2 & Juli 2018 & 167 & 59 & 226 \\
\hline
\end{tabular}

Sumber: Data Olahan Peneliti 2018

Berdasarkan data di atas bahwa pelayanan administrasi kependudukan masih belum berjalan optimal di Kelurahan Gempolsari. kurangnya kesigapan aparat pemerintah yang ada di Kelurahan Gempolsari dalam memberikan pelayanan kepada masyarakat. Hal lainnya menjadi dasar dari penelitian ini bahwa dalam memberikan pelayanan Kelurahan Gempolsari masih kurang responsive kepasa masyarakat, tidak adanya SOP yang jelas. Seharusnya pelayanan public yang diberikan kepada masyarakat mampu memenuhi kebutuhan masayarakat dan cepat tanggap kepada kebutuhan masyarakat. publik maupun jasa publik yang pada prinsipnya menjadi tanggungjawab dan dilaksanakn oleh instansi pemerintah di pusat, di daerah, dan di lingkungan Badan Usaha Milik Negara atau Badan Usaha Milik Daerah, dalam upaya pemenuhan kebutuhan masyrakat maupun dalam rangka pelaksanaan ketentuan peraturan perundang-undang. 
Penelitian ini menggunakan penelitian yang sifatnya deskriftif dengan pendekatan kualitatif. Metode penelitian deskriftip merupakan salah satu cara guna mengetahui atau menggambarkan penelitian yang dilakukan terhadap variabel mandiri atau tunggal, yaitu tanpa membuat perbandingan atau menghubungkan dengan variabel ini, sehingga memudahkan peneliti untuk mendapatkan data objektif dalam rangka mengetahui dan memahami Kapabilitas Aparat Pemerintah Daerah Dalam Memberikan Pelayanan Administrasi Kependudukan di Kelurahan Gempolsari Kota Bandung.

\section{PEMBAHASAN}

\section{Kapabilitas Aparat Pemerintah Daerah dalam memberikan Pelayanan} Administrasi Kependudukan di Kelurahan Gempolsari Kota Bandung

Kapabilitas Aparat Pemerintah dalam memberikan pelayanan administrasi kependudukan di Kelurahan Gempolsari Kota Bandung saat ini belum berjalan dengan baik, hal ini karena aparat Pemerintah Kelurahan Gempolsari belum begitu kompeten dalam memberikan pelayanan administrasi kependudukan. Sehingga menimbulkan anggapan bahwa kurang efektifnya waktu dalam pengerjaan pembuatan administrasi kependudukan, adanya tindakan diskriminatif oleh aparat Pemerintah kepada masyarakat, kurangnya sarana dan prasarana penunjang seperti area parkir, sumber daya manusia yang tidak memadai yang seharusnya ada penambahan pegawai di bagian pelayanan administrasi kependudukan Kelurahan Gempolsari. Adapun untuk mengukur kapabilitas aparat Pemerintah di Kelurahan Gempolsari, peneliti menggunakan dimensi: Pengetahuan dan keterampilan, Sistem Teknis, Sistem Manajerial, dan Nilai dan Norma.

\section{Pengetahuan dan Keterampilan}

Kapabilitas ialah kemampuan mengeksploitasi secara baik sumber daya yang dimiliki dalam diri maupun di dalam organisasi, serta potensi diri untuk menjalankan aktivitas tertentu ataupun serangkaian aktivitas. Berbicara kapabilitas berarti berbicara Kinerja (Performance), kinerja 
menjadi isu Dunia saat ini. Hal tersebut terjadi sebagai konsekuensi tuntutan masyarakat terhadap kebutuhan akan pelayanan prima atau pelayanan yang bermutu tinggi. Melalui kinerja Aparatur, diharapkan akan menunjukan profesionalnya secara nyata dalam meningkatkan mutu pelayanan public secara umum pada tempatnya bekerja, dan tampak akhir bermuara pada kualitas hidupdan kesejahteraan masyarakat. Kata kinerja (performance) dalam konteks tugas, sama dengan prestasi kerja.

Kapabilitas adalah penampilan yang melakukan, menggambarkan dan menghasilkan sesuatu hal, baik yang bersifat fisik dan non fisik yang sesuai dengan petunjuk, fungsi dan tugasnya yang didasari oleh pengetahuan, sikap, keterampilan, dan motivasi. Setiap individu atau organisasi tentu memiliki tujuan yang akan dicapai dengan menetapkan target atau sasaran. Keberhasilan individu atau organisasi dalam mencapai target atau sasaran tersebut merupakan kinerja.

\section{a. Pengetahuan dalam memberikan pelayanan}

Dalam memberikan suatu pelayanan diperlukan pengetahuan yang cukup, dengan pengetahuan yang cukup akan mampu mengoptimalkan kinerja dari aparat Pemerintah selaku pemberi pelayanan agar tidak terjadi kekeliruan dalam memberikan suatu pelayanan dan mampu bekerja dengan cepat dan tanggap.

Hasil wawancara yang peneliti lakukan dengan kepala Seksie Pemerintahan di Kelurahan Gempolsari Kota Bandung, mengenai kemampuan aparat Pemerintah Kelurahan Gempolsari dalam memberikan pelayanan administrasi kependudukan mengatakan bahwa:

"Aparat Pemerintah memang tugasnya kepanjangtanganan Pemerintah, otomatis kita ada panduan buku seperti sekarang yang bergulir yaityu mengimplementasikan dari Peraturan Undang-Undang no 2 Tahun 2013 dan sekarang ada pembaharuan Perwal no 215 Tahun 2018 mengenai tata cara memberi pelayanan baik itu dari pengurus RT dan RW maupun sampai kepada pelayan masyarakat. Mengapa demikian, karena yang menjadi tolak ukur kita itu adalah pengurus RT setempat jadi, kita harus memberikan edukasi kepada pengurus RT dan pembekalan bagaimana tugas RT dan RW sesuai tupoksinya mengenai pelayanan publik. Sekarang ini sudah masuk era terbuka yang menganut e-government yang bersih dari segala hal yang tidak layak. Alhamdulilah di Kelurahan Gempolsari sudah 
ditetapkan bahwa pelayanan itu tanpa ada pungutan biaya apalagi masalah kependudukan, keperluan hal-hal yang sifatnya pelayanan publik kepada masyarakat wajib hukumnya kita memberi bantuan tanpa ada beban apapun sesuai dengan amanat Undang-Undang yang berlaku".

Selanjutnya kegiatan wawancara yang peneliti lakukan dengan masyarakat yang ada di wilayah Gempolsari mengenai kemampuan aparat Pemerintah Kelurahan Gempolsari dalam memberikan pelayanan administrasi kependudukan mengatakan bahwa:

"Menurut saya, aparat Pemerintah di Kelurahan khususnya Kelurahan Gempolsari belum terasa maksimal dalam memberikan pelayanan khususnya pelayanan administrasi kependudukan. Hal tersebut dikarenakan kualitas aparat yang dirasa kurang karena tidak ada kesigapan dalam memberikan pelayanan."

Pegawai Kelurahan Gempolsari sudah sangat paham namun dalam pengimplentasiannya belum berjalan maksimal sehingga masyarakat banyak yang mengeluhkan pelayanan yang diberikan oleh Aparat Pemerintah Kelurahan Gempolsari. Adanya mis komunikasi antara aparat Pemerintah Kelurahan Gempolsari dengan masyarakat sebagai pemohon karena dengan begitu optimalnya pelayanan yang sudah diberikan tetapi masih saja dirasa kurang. Hal tersebut terjadi karena aparat Pemerintah selaku pemberi pelayanan tidak mampu memuaskan pemohon dalam memberikan pelayanan di Kelurahan Gempolsari Kota Bandung.

\section{b. Keterampilan dalam memberikan Pelayanan}

Keterampilan (skil) sangat diperlukan mengingat bahwa dalam memberikan suatu pelayanan kualitas aparat Pemerintah sangat diperhitungkan, keterampilan yang dimiliki menentukan kualitas kinerja aparat Pemerintah. Dengan keterampilan yang dimiliki akan mampu mengoptimalkan kinerja aparat Pemerintah. Wawancara yang peneliti lakukan dengan Kepala Seksie Pemerintahan di Kelurahan Gempolsari Kota Bandung, mengenai keterampilan dari pihak terkait dalam memberikan pelayanan, mengatakan bahwa:

"ASN yang ada di Kelurahan Gempolsari sudah sedemikian rupa di latih oleh Pemerintah pusat dan diberi pendidikan untuk menghadapi 
masyarakat yang karakternya berbeda dari a sampai $z$ yang karena itulah kita harus dibekali dengan pengetahuan jangan sampai nanti kita memberikan suatu pelayanan yang sulit dipahami oleh masyarakat dan harus sesuai porsi kebutuhan dimana masyarakat itu berada. Seperti contoh masyarakat yang tinggal di komplek yang sudah sedemikian bagus dalam memahami aturan Perda atau Perwal berbeda dengan yang tinggal di perkampungan yang masih asri belum tentu memahami jadi kita harus memberikan edukasi sesuai dengan kemampuan yang ada di benak masyarakat."

Berdasarkan kegiatan wawancara yang peneliti lakukan dengan ketua RW 07 Kelurahan Gempolsari, mengenai keterampilan dari pihak terkait dalam memberikan pelayanan, apakah sudah menunjang proses pelayanan mengatakan bahwa:

"untuk pelayanan di Kelurahan Gempolsari itu sangat profesional untuk pelayanan pengantar atau rekomendasi untuk pembuatan surat-surat terutama Kartu Keluarga dan Akta Kelahiran."

Selanjutnya kegiatan wawancara yang peneliti lakukan dengan masyarakat yang ada di wilayah Gempolsari mengenai mengenai keterampilan dari pihak terkait dalam memberikan pelayanan, apakah sudah menunjang mengatakan bahwa:

"Seperti yang sudah saya jelaskan sebelumnya aparat terkait kurang sigap dalam memberikan pelayanan karena terkesan lambat dan mengulurngulur waktu. Contohnya seperti apabila ada kekurangan persyaratan aparat terkait tidak menyebutkan secara rinci apa saja persyaratan yang kurang sehingga pemohon harus bulak-balik sehingga jadi banyak waktu yang terbuang."

Aparat Pemerintah kurang sigap dan lambat dalam memberikan pelayanan kepada masyarakat khususnya dalam bidang administrasi kependudukan. Dengan pernyataan kasi Pemerintahan bahwa mereka selalu memberikan edukasi kepada masyarakat sesuai kemampuan masyarakat itu sendiri ternyata belum dilakukan dengan baik karena dengan sudah diberikannya edukasi kepada masyarakat seharusnya masyarakat sudah mengerti dan tidak adanya lagi kesalahan dalam pengajuan persyaratan yang membuat masyarakat jadi bulak-balik dan membuang-buang waktunya. Pemberian edukasi hanya diberikan kepada 
RW dan RT saja sehingga yang memahamipun hanya sebatas RW dan RT saja. Adanya perbedaan pendapat antara pemohon pengajuan pelayanan administrasi kependudukan karena, ada yang menyatakan proses pelayanan administrasi kependudukan di Kelurahan Gempolsari sudah baik ada juga yang menyatakan bahwa proses pelayanan administrasi kependudukan di Kelurahan Gempolsari belum berjalan dengan baik, padahal mereka sama-sama berstatus sebagai pemohon pelayanan administrasi kependudukan.

Atas dasar dimensi pengetahuan dan keterampilan peneliti mengasumsikan bahwa sebenarnya pengetahuan yang dimiliki oleh Aparat Pemerintah Kelurahan Gempolsari sudah sangat paham betul baik secara teknisnya maupun non teknis namun kendati demikian mereka bekerja sudah sesuai dengan SOP yang berlaku, hal lain menunjukan bahwa pengetahuan tersebut belum sepenuhnya diimplementasikan oleh aparat Pemerintah Kelurahan Gempolsari karena masih saja ada diskriminatif dalam pemberian pelayanan semisal ketika peneliti akan membuat sebuah administrasi kependudukan terkadang sangat lamban dalam pengerjaannya namun apabila peneliti pergi dengan orang yang memiliki jabatan seperti RW maka pelayanannya akan serba cepat. Hal ini menunjukan sebetulnya harus ada pengawasan dari intasi Kelurahan Gempolsari kepada individu/pegawai supaya dapat memberikan pelayanan yang berkualitas.

\section{Sistem Teknis}

Dalam sebuah organisasi khususnya organisasi Pemerintahan seperti halnya di Kelurahan Gempolsari, harus memperhatikan sistem teknis yang menunjang sarana dan prasarana serta sumber daya manusia yang mendukung proses pelayanan. Apabila keduanya sudah baik maka proses pelayanan juga akan optimal dan sesuai dengan harapan masyarakat.

\section{a. Sarana dan Prasarana pendukung pelayanan}

Sarana merupakan segala sesuatu yang dapat dipakai sebagai alat dalam mencapai maksud dan tujuan. Sedangkan prasarana merupakan segala sesuatu yang merupakan penunjang utama terselenggaranya suatu 
proses (usaha, pembangunan, proyek). Untuk memudahkan untuk membedakan keduanya yaitu sarana lebih ditujukan untuk benda-benda yang bergerak seperti komputer dan mesin-mesin, sedangkan prasarana lebih ditujukan untuk benda-benda yang tidak bergerak seperti gedung.

Hasil wawancara yang peneliti lakukan dengan masyarakat yang ada di wilayah Gempolsari Kota Bandung, mengenai pendapat Bapak atau Ibu terkait dengan sarana dan prasarana pendukung proses pelayanan administrasi kependudukan mengatakan bahwa:

"Sarana dan Prasarana penunjang pelayanan di Kelurahan Gempolsari masih sangat minim apalagi untuk area parkir yang sangat kecil sehingga masyarakat sebagai pemohon pelayanan tidak jarang parkir di depan rumah warga yang terlihat tidak rapih dan memakan jalan. Di tambah lagi komputer yang ada dibagian pelayanan hanya ada satu dan jadi mengurangi proses pelayanan."

Selanjutnya kegiatan wawancara yang peneliti lakukan dengan ketua RW 07 Kelurahan Gempolsari, mengenai pendapat Bapak atau Ibu terkait dengan sarana dan prasarana pendukung proses pelayanan administrasi kependudukan mengatakan bahwa:

"Untuk sarana dan prasarana alat pembantu di Kelurahan itu sangat minim, mungkin itu juga faktor dari Pemerintah Kota yang belum maksimal, masih perlu pembenahan dan perlu penunjang untuk alat maupun tempat.Sarana dan prasarana di kelurahan Gempolsari kurang memadai khususnya lokasi parkir dan diharapkan mampu mengembangkan informasi melalui media elektronik."

Sarana dan prasarana yang ada di Kelurahan Gempolsari Kota Bandung khususnya prasarana seperti area parkir lahannya sangat sempit dan tidak memadai bahkan kurang bisa menampung kendaraan baik kendaraan milik pegawai maupun kendaraan masyarakat sebagai pemohon administrasi kependudukan. Masalah lain yang dihadapi oleh aparat Pemerintah Kelurahan Gempolsari yaitu kurangnya sarana dan prasarana untuk media pemberi layanan seperti komputer yang hanya memiliki satu saja dan tentu seharusnya pemerintah Kelurahan Gempolsari membuat anggaran untuk menambah komputer. 


\section{b. Sumber Daya Manusia yang mendukung}

Sumber daya manusia yang berkualitas penting adanya dalam proses pelayanan khususnya administrasi kependudukan, dengan kualitas sumber daya manusia yang baik maka kinerjanyapun akan baik dan tidak mengecewakan masyarakat selaku pemohon. Sumber daya manusia yang berkualitas menentukan pelayanan yang cepat dan optimal.

Berdasarkan hasil wawancara yang peneliti lakukan dengan Lurah di Kelurahan Gempolsari Kota Bandung, mengenai kapasitas aparatur sumber daya manusia sebagai pelaksana pemberi pelayanan di Kelurahan Gempolsari mengatakan bahwa:

"Kalau untuk aparat Kelurahan Gempolsari alhamdulillah disini sudah hampir rata-rata sudah sarjana, kemudian golonganpun sudah memadai sehingga pelayanan kepada masyarakat yang memang Gempolsari itu hampir $70 \%$ ada di lingkungan perumahan yang notabene berpendidikan tinggi sehingga kami memberi pelayanan di Kelurahan Gempolsari tidak ada kendala yang berarti jadi semua bisa diatasi dengan baik."

Hasil wawancara yang peneliti lakukan dengan masyarakat yang ada di wilayah Gempolsari Kota Bandung, mengenai kapasitas aparatur sumber daya manusia sebagai pelaksana pemberi pelayanan di Kelurahan Gempolsari mengatakan bahwa:

"Menurut saya, sumber daya manusia juga masih kurang karena hanya ada satu orang saja di bagian pelayanan sehingga membuat antrian panjang dan agak lama."

Sumber daya yang ada di Kelurahan Gempolsari Kota Bandung sudah sangat memadai karena pegawainya terdiri dari golongan yang secara akademis cukup tinggi sehingga dapat dengan mudah mengerti dalam menjalankan tugasnya, namun dari segi kuantitas pegawai Kelurahan Gempolsari Kota Bandung sangat minim dan seharusnya melakukan rekrutmen kembali supaya Sumbe Daya Manusia di Kelurahan Gempolsari dapat dengan mudah memberikan pelayanan, karena secara teknispun sebenarnya kuantitas sangat berpengaruh.

Atas dasar dimensi sistem teknis bahwa dalam sarana prasarana pendukung pelayanan di Kelurahan Gempolsari Kota Bandung sampai saat 
ini kurang memadai karena hanya memiliki satu komputer sehingga menghambat efektifiitas dari pelayanan, sedangkan prasarana yang belum memadai yaitu lahan parkir yang sempit kemudian Sumber Daya Manusia yang mendukung sudah cukup mampu namun perlu ada perekrutan kembali untuk menambah kuantitas dari pegawai Kelurahan Gempolsari Kota Bandung.

\section{Sistem Manajerial}

Manajemen adalah tindakan memikirkan dan mencapai hasil-hasil yang diinginkan melalui usaha kelompok yang terdiri dari mendayagunakan bakat- bakat manusia dan sumber-sumber daya. Sistem manajerial dalam suatu organisasi sangat diperlukan untuk mampu mengelola sumber daya, karena untuk mencapai suatu tujuan yang hendak dicapai bersama memerlukan kerjasama tim yang baik. Adanya sistem manajerial dalam suatu organisasi khususnya organisasi Pemerintahan seperti Kelurahan Gempolsari akan mampu memanfaatkan skill yang dimiliki oleh aparat Pemerintah dalam memberikan pelayanan khususnya administrasi kependudukan agar mampu menunjang proses pelayanan.

\section{a. Kemampuan dalam memberikan pelayanan}

Kemampuan individu di dalam organisasi menentukan kapasitas seorang individu untuk melakukan beragam tugas dalam suatu pekerjaan. Kemampuan seorang individu yang baik akan dapat mengendalikan setiap persoalan yang dihadapi di dalam suatu organisasi sehingga tidak akan menghambat proses tercapainya tujuan yang ingin dicapai bersama. Kemampuan dalam memberikan pelayanan khususnya pelayanan administrasi kependudukan dilihat dari kualitas aparat Pemerintah sebagai pemberi pelayanan apakah memang sudah mampu atau belum. Dengan kemampuan yang dimiliki aparat Pemerintah akan mengoptimalkan dalam pemberian pelayanan kepada masyarakat sebagai pemohon dan mampu menunjang proses pelayanan.

Berdasarkan kegiatan wawancara yang peneliti lakukan dengan kepala seksie pemerintahan di Kelurahan Gempolsari Kota Bandung, mengenai kemampuan dari pihak terkait dalam mengolah dan mengatur 
pelayanan administrasi kependudukan mengatakan bahwa:

"Kalau masalah mengolah administrasi kependudukan sifatnya itu kita harus langsung kepada masyarakat itu sendiri berdasarkan aturan regulasi yang sudah ditetapkan. Contohnya masyarakat di wajibkan memiliki identitas bahkan menjelang perhelatan akbar Pilpres 2019, tapi keadaan disisi lain dalam pembuatan KTP itu susah keluar dan ini sudah bukan rahasia umum. Kita selaku aparat Pemerintah sudah mentaati UndangUndang yang berlaku tapi fakta di lapangan demikian, namun demikian kitapun harus memberi optimisme kepada masyarakat".

Selanjutnya kegiatan wawancara yang peneliti lakukan dengan masyarakat yang ada di wilayah Gempolsari mengenai mengenai kemampuan dari pihak terkait dalam mengolah dan mengatur pelayanan administrasi kependudukan mengatakan bahwa:

"Sama seperti sebelumnya saya tidak puas dengan pelayanan yang diberikan Kelurahan Gempolsari Kota Bandung, karena yang saya rasakan pelayanan di Kelurahan tersebut kurang maksimal apalagi yang mengurus pengajuan pelayanan administrasi sendiri itu lama berbeda dengan yang meminta bantuan kepada RW atau aparat terkait sebagai mediator bisa dibilang sebentar dan langsung jadi dan juga tidak dipersulit, dengan proses pemberian pelayanan yang seperti itu bisa dibilang aparat Pemerintah Kelurahan gempolsari pandang bulu dalam memberikan pelayanan kepada masyarakat."

Kemampuan aparat Pemerintah Kelurahan Gempolsari dalam memberikan pelayanan sudah berupaya maksimal dengan regulasi yang berlaku tetapi faktanya yang dirasakan masyarakat belum maksimal penyebabnya aparat Pemerintah Kelurahan Gempolsari kadang pandang bulu dalam memberikan pelayanan administrasi kependudukan. Atas dasar dimensi Sistem Manajerial mengenai kemampuan dalam memberikan pelayanan untuk administrasi kependudukan, Kelurahan Gempolsari sudah berupaya supaya sesuai aturan yang ditetapkan sehingga mengurangi kesalahan-kesalahan non teknis, hanya ada beberapa urusan administrasi kependudukan yang tidak di handle oleh aparat Kelurahan Gempolsari karena terbentur dengan intansi lain seperti kecamatan, apabila dari kelurahan pendataannya sudah cepat namun dari kecamatan terkadang lamban. 


\section{Nilai dan Norma}

Untuk menilai kebaikan seorang aparat Pemerintah harus dipertanyakan agamanya yang biasa disebut dengan SQ (spritual question) dan dipilah-pilih masalah agamanya (spiritual quotient). Namun keberadaan agama terkadang berlainan misalnya apabila seorang pejabat pemerintah tersebut menempatkan kasih diatas segala-galanya, dalam pandangan agama walaupun harus mengasihi sesama umat manusia tapi tidak dengan orang jahat, jadi kasih itu ditujukan kebaikan itu sendiri, jadi bukan melindungi kejahatan dan dekadensi moral.

Ada beberapa norma yang berlaku di masyarakat seperti norma Agama, norma Kesopanan, dan norma Hukum. Ketiga norma tersebut harus diterapkan pada aparat Pemerintah selaku pemberi pelayanan. Aparat pemerintah harus bekerja sesuai dengan norma agama, apabila aparat terkait mampu taat kepada penciptanya maka dia akan melaksanakan apa yang diperintahkan dan menjauhi larangan penciptanya. Apabila sudah demikian aparat Pemerintah tidak akan melakukan penyimpangan dalam melakukan proses pelayanan. Norma kesopanan merupakan peraturan yang timbul dari pergaulan segolongan manusia yang diikuti dan ditaati sebagai pedoman yang mengatur tingkah laku manusia terhadap lingkungan sekitarnya, dengan demikian apabila aparat Pemerintah menerapkan norma kesopanan pada hidupnya maka tidak akan ada perlakuan yang tidak sopan atau tidak menghargai yang dilakukan aparat terkait terhadap pemohon pelayanan, terutama bagaimana cara menerapkan norma kesopanan dalam memberikan pelayanan kepada pemohon yang lebih tua yang sudah seharusnya di hormati dan dilayani dengan baik.

Aparat Pemerintah harus bekerja sesuai dengan norma hukum karena dengan demikian peraturan yang sudah ditetapkan akan mengikat setiap orang agar mematuhi dan tidak melanggarnya dan aparat terkait apabila sudah melakukan pekerjaan berdasarkan norma hukum maka akan melaksanakan suatu pekerjaan yang benar dan tidak melanggar aturan yang berlaku. 


\section{a. Peraturan dalam proses pelayanan}

Dalam menjalankan sesuatu apapun yang ada di kehidupan masyarakat harus dilakukan berdasarkan aturan yang berlaku, segala sesuatu yang dilakukan dengan mengikuti aturan maka akan bejalan dengan baik, rapih dan tertib. Seperti dalam proses pelayanan agar tidak terjadi penyimpangan dan kesalahan maka prosesnya juga harus dijalankan berdasarkan aturan yang sudah ditetapkan. Dengan begitu, pemberi dan pemohon juga akan mendapatkan hasil yang optimal dan akan sama-sama terpuaskan.

Aturan yang sudah ditetapkan dalam proses pelayanan tidak boleh dilanggar, karena apabila dilanggar akan menjadi penyakit birokrasi. Aturan diberlakukan dalam proses pelayanan agar dapat mengikat setiap individu baik pemberi maupun pemohon pelayanan agar tetap dalam koridor hukum yang sudah ditetapkan dan tidak terjadi pelanggaran. Berdasarkan hasil wawancara yang peneliti lakukan dengan Lurah di Kelurahan Gempolsari Kota Bandung, mengenai peraturan atau prosedur yang seharusnya dijalankan dalam memberikan pelayanan di Kelurahan Gempolsari mengatakan bahwa:

"Kalau untuk peraturan kita mengacu kepada Perwal yang sudah ditentukan oleh tingkat Kota Bandung, sehingga kami dalam memberikan pelayanan selalu memberitahukan yang secara rinci apa saja pelayanan yang akan diberikan sesuai dengan persyaratan-persyaratan yang harus ditaati oleh pemohon."

Selanjutnya kegiatan wawancara yang peneliti lakukan dengan kepala seksie pemerintahan di Kelurahan Gempolsari Kota Bandung, mengenai peraturan atau prosedur yang seharusnya dijalankan dalam memberikan pelayanan di Kelurahan Gempolsari mengatakan bahwa:

"Prosedur yang harus dilaksanakan oleh masyarakat perihal pelayanan administrasi kependudukan sudah dikeluarkan ketentuannya yang pertama harus penduduk asli disini dilengkapi dengan Kartu Keluarga, yang kedua segala sesuatunya harus melalui RT dan RW terlebih dahulu supaya datanya itu nyambung antara RT, RW dan Kelurahan. Dan tidak lupa kami selalu mengingatkan dan menghimbau kewajiban mengenai PBB yang harus dilunasi." 
Dalam melaksanakan tugasnya aparat Pemerintah Kelurahan Gempolsari sudah sesuai peraturan dan mengacu kepada perwal yang ditentukan oleh Pemerintah Kota Bandung sehingga dalam pengerjaan atau pelayanan tentu sesuai dengan ketentuan yang berlaku yaitu harus penduduk asli dan dilengkapi dengan kartu keluarga, harus melalui RT dan RW terlebih dahulu supaya ada kesesuaian data antara RT, RW dan Kelurahan.

\section{b. Tata Krama}

Di era modern saat ini yang perkembangan teknologinya sangat pesat dan mudah di akses oleh siapapun. Dalam perkembangannya teknologi yang maju ini juga memberikan dampak yang positif maupun negatif bagi penggunanya. Dengan mudahnya mengakses internet oleh siapapun tidak jarang mempengaruhi perilaku penggunanya khususnya pengguna yang masih sangat muda dan mudah terpengaruhi.

Tata krama dalam kehidupan bermasyarakat sangat dijunjung tinggi karena mempengaruhi kualitas hidup manusia dalam berinteraksi dengan masyarakat. Tidak jarang kita temui anak muda yang tidak memiliki sopan santun terhadap yang lebih tua, hal tersebut terjadi karena banyaknya tontonan yang tidak bermoral di internet yang dengan mudahnya di akses oleh anak muda yang masih labil dan mudah terpengaruhi.

Di dalam proses pelayanan juga harus ada tata kramanya khususnya dalam memberikan pelayanan kepada yang lebih tua karena dengan sopan santun yang baik maka akan memudahkan pelayanan dan dimengerti oleh pemohon pelayanan. Sebagai pemberi pelayanan sudah seharusnya bertindak ramah dan tidak mudah marah karena tidak semua pemohon mengerti akan prosedur yang ada khususnya pemohon yang ada di perkampungan.

Hasil wawancara yang peneliti lakukan dengan masyarakat yang ada di wilayah Gempolsari Kota Bandung terkait dengan tata krama dalam proses pelayanan yang diberikan mengatakan bahwa:

"Menurut saya, aparat Pemerintah yang ada di Kelurahan Gempolsari sudah cukup ramah dan ada sopan santunya juga, tapi ada beberapa 
aparat yang kurang ramah terutama menghadapi pemohon yang menyebalkan. Seharusnya sebagai pemberi pelayanan mampu menyikapi tingkahlaku pemohon yang tidak sesuai dengan aturan dan tetap memberi pengarahan sebagai mana mestinya sampai pemohon mengerti. Sabar memang kunci dalam memberikan suatu pelayanan."

Kelurahan Gempolsari sudah menjalankan tata krama yang baik dalam proses memberikan pelayanan, ramah tamah dan sopan santunpun sudah dijalankan walaupun terkadang memang ada beberapa aparat terkait yang mudah terpancing emosinya dalam menghadapi pemohon yang menyebalkan. Hal tersebut terjadi karena adanya miss komunikasi antara pemberi dan pemohon pelayanan.

Pemberian tatakrama dalam pelayanan aparat Pemerintah Kelurahan Gempolsari memiliki konsep 3S yaitu Senyum, Sapa, Salam sehingga dalam memberikan pelayanan selalu dengan keramah tamahan dan penelitipun melihat bahwa yang terjadi dilapangan konsep ini sudah teremplementasikan dan dirasakan oleh masyarakat Gempolsari.

Aparat Pemerintah Kelurahan Gempolsari Kota Bandung memberikan pelayanan kepada masyarakat sudah sesuai dengan peraturan dalam proses pelayanan dan mengacu kepada Perwal Kota Bandung yang berlaku kemudian dalam memberikan pelayanan aparat Pemerintah Kelurahan Gempolsari sudah sesuai konsep yang berlaku yaitu 3S Senyum, Sapa, Salam.

\section{KESIMPULAN}

Berdasarkan hasil penelitian serta pembahasan mengenai Kapabilitas Aparat Pemerintah Daerah dalam memberikan pelayanan administrasi kependudukan di Kelurahan Gempolsari Kota Bandung, maka peneliti mengambil kesimpilan dari hasil penelitian sebagai berikut:

1. Meninjau dari Pengetahuan dan Keterampilan walaupun sudah dibekali ilmu dan menjalankan proses pelayanan administrasi kependudukan sesuai dengan ketetapan hukum dan prosedur yang berlaku namun tetap saja pelayanan yang diberikan aparat Pemerintah Kelurahan Gempolsari 
belum memuaskan, hal tersebut dikarenakan kualitas aparat Kelurahan Gempolsari kurang memadai, dengan hal tersebut maka aparat Kelurahan Gempolsari menjadi tidak sigap dalam memberikan pelayanan dan juga prosesnya terbilang lama sehingga masyarakat sebagai pemohon pelayanan administrasi kependudukan merasa pelayanan yang diberikan oleh Kelurahan Gempolsari belum cukup baik.

2. Meninjau dari Sistem Teknis, sarana dan prasarana di Kelurahan Gempolsari masih sangat minim terutama prasarana seperti area parkir yang kurang luas dikarenakan lahannya yang sangat kecil sehingga membuat pemohon menjadi parkir sembarangan di depan rumah warga. Karena tidak disediakannya lahan parkir oleh Kelurahan Gempolsari masyarakat yang parkir sembarangan tersebut jadi mengurangi keindahan perumahan warga setempat.

3. Meninjau dari Sistem Manajerial aparat Kelurahan Gempolsari sudah secara langsung melayani dan memberi edukasi tentang bagaimana proses pelayanan tersebut, namun walaupun sudah menjalankan proses pelayanan sesuai dengan prosedur yang berlaku tetap saja masyarakat ada yang tidak mengerti tata cara pengajuan proses pelayanan administrasi kependudukan.

4. Meninjau dari Nilai dan Norma khususnya peraturan dan tata krama aparat Pemerintah Kelurahan Gempolsari sudah menjalankannya dengan baik sesuai dengan prosedur yang berlaku, aparat Pemerintah Kelurahan Gempolsari sudah menjalankan proses pelayanan administrasi kependudukan dengan step by step di mulai dari RT, RW lalu ke Kelurahan dengan tujuan agar data pemohon sesuai dan tidak berubah. Tata krama seperti ramah dan sopan santunpun sudah aparat lakukan dengan baik. 


\section{DAFTAR PUSTAKA}

\section{Buku :}

Amir, Taufiq M. 2011. Manajemen Strategik Konsep dan Aplikasi. Jakarta: Rajawali Pers.

Arikunto, Suharsimi. 2006. Prosedur Penelitian: Suatu Pendekatan Praktik. Yogyakarta: PT. Rineka Cipta.

Handayaningrat, Soewarno.1996.Pengantar Studi Ilmu Administrasi dan Manajemen. Jakarta : CV. Haji Masagung.

Hardiyansyah. 2011.kualitas Pelayanan Publik.Yogyakarta: Gava Media.

Kusumasari, Bevaola. 2014.Manajemen Bencana dan Kapabilitas Pemerintah Lokal. Yogyakarta: Gava Media.

Moenir,H.A.S. 2006. Manajemen Pelayanan Umum di Indonesia. Jakarta: PT. Remaja Rosdakarya.

Moleong, Lexy J. 2016. Metodologi Penelitian Kualitatif, Bandung: PT. Remaja Rosdakarya.

Musanef. 1996. Manajemen Kepegawaian di indonesia. Michigan: PT GUNUNG AGUNG.

Prajudi.1982. Administrasi dan Manajemen Umum. Jakarta : Ghalia Indonesia.

Rasyid, M. Ryaas. 2000. Kajian Awal Birokrasi Pemerintahan dan Publik Orde Baru, Jakarta: Yarsif Watampine.

Ratminto \& Atik Septi Winarsih. 2006. Manajemen Pelayanan, Jakarta: Pustaka Pelajar.

Setyawan.2007. Manajemen Pemerintahan Indonesia. Jakarta: Djambatan.

Sinambela, Lijan. 2006. Reformasi Pelayanan Publik. Jakarta: PT. Bumi Aksara.

Sugiyono. 2016. Metode Penelitian Kuantitatif Kualitatif dan R\&D. Bandung: CV Alfabeta.

Syafiie, Inu Kencana. 2001. Pengantar Imu Pemerintahan. Bandung: CV. Ramadhan.

Widodo, Joko. 2001. Etika Birokrasi dalam Pelayanan Publik. Malang: CV. Citra Malang.

Wijaya,H.AW. 2002. Otonomi Daerah dan Daerah Otonom. Jakarta: Raja Grafindo Persada. 


\section{Dokumen:}

Peraturan Pemerintah No 73 Tahun 2005 tentang Kelurahan.

Undang-Undang Nomor 24 Tahun 2013 Tentang Administrasi Kependudukan. Undang-undang No. 24 Tahun 2014 tentang Administrasi Kependudukan.

LAKIP Kecamatan Bandung Kulon Kota Bandung

\section{Jurnal :}

Abd. Rais Asmar. Pelayanan Publik Di Bidang Administrasi Kependudukan. 2017.

Jenilda Paputungan Martha Ogotan Femmy.M.G. Tulusan. Pemberdayaan Aparat Kelurahan Dalam Meningkatkan Kualitas Pelayanan Publik.2014

Erlanda Juliansyah Putra. Pengelolaan Kepegawaian Pada Era Otonomi Daerah.2015

\section{Daftar Website :}

http:/ /jabar.tribunnews.com/2018/02/28/30-ribu-warga-bandung-belumrekam-e-

ktp-paling-banyak-di-4-kecamatan-ini 15 Agustus 2018 